\title{
Loss of Heterozygosity on Chromosome Arm 3p in Nasopharyngeal Carcinoma
}

\author{
Li-Fu Hu, Gudny Eiriksdottir, Tatyana Lebedeva, Irina Kholodniouk, Andrei Alimov, Fu Chen, Yan Luo, \\ Eugene R. Zabarovsky, Sigurdur Ingvarsson, George Klein, and Ingemar Ernberg \\ Microbiology and Tumor Biology Center (MTC), Karolinska Institute, Stockholm, Sweden (L.-F.H., T.L., I.K., A.A., F.C., E.R.Z., G.K., \\ I.E.); Department of Pathology, National University Hospital, Reykjavik, Iceland (G.E., S.I.); Guangdong Provincial Hospital, Guangdong, \\ China (Y.L.); Institute of Molecular Biology, Koltsovo, Novosibirsk, Russia (T.L.)
}

We have examined 17 primary undifferentiated nasopharyngeal carcinoma biopsies for allelic loss on 3p, comparing the findings in tumors with those in normal lymphocyte DNA from the same patients. Ten polymorphic microsatellite markers were used between $3 p / 3$ and 3p26. Allelic loss was observed in 12 samples (70\%). Two loci were most frequently affected: D3S1067 (3p21.1-14.3) in 60\% and D3S1217 (3p|4.2-14.1) in 58\%. One tumor seemed to have a homozygous deletion at 3p26, detected by the D3S 1297 marker. Analysis of the clinical data showed that an increased number of aberrations in 3p was correlated with more advanced tumor stages. Genes Chromosom Cancer 17:1/8-126 (1996). (c) 1996 Wiley-Liss, Inc.

\section{INTRODUCTION}

Nasopharyngeal carcinoma (NPG) is the most common malignancy in males in certain populations in Southern China. The incidence per year is 32 per $10^{5}$ in the Guangzhou region $\left(11 \times 10^{6}\right.$ population). NPC is also relatively frequent among the Eskimos of Greenland and Alaska, and it shows a moderate incidence in North Africa.

NPC is believed to have a multifactorial etiology. Epstein-Barr virus (EBV), environmental carcinogens, and genetic factors have been implicated. EBV DNA is detected in $100 \%$ of undifferentiated NPC (Klein et al., 1974).

Cytogenetic studies of NPC biopsy specimens and xenografts have detected structural changes in chromosome 3 (Huang et al., 1989). These researchers also found loss of heterozygosity ( $\mathrm{LOH}$ ) in the short arm of chromosome 3 in all informative cases at two sites, 3p25 (RAF1) in 10 of 10 cases and 3p14 (D3S3) in 9 of 9 cases, using Southern hybridization with polymorphic probes (Huang et al., 1991). Deletions in 3p are thus common in NPG.

In renal cell carcinoma of the clear cell type (RCC), 3p losses occur in nearly 90\% (Kovacs et al., 1988; van der Hout et al., 1993). In the majority of the RCC, LOH has been detected at 3p25, 3p21, and 3p13-p14 (Yamakawa et al., 1991; Foster et al., 1994; van den Berg et al., 1995).

Recently, the gene responsible for von Hippel Lindau disease (VHL; 3p25-26) was found to be mutated in more than $50 \%$ of RCC and LOH was detected in $84 \%$ and $98 \%$ of the tumors (Gnarra et al., 1994; Shuin et al., 1994). However, mutations were not found in NPC (Sun et al., 1995b), sug- gesting that this gene may not be involved in the development of NPC.

In human lung cancer, allelic losses occur most frequently at regions $3 \mathrm{p} 25,3 \mathrm{p} 21-\mathrm{p} 22$, and $3 \mathrm{p} 13-$ p14 (Hibi et al., 1992; Yokoyama et al., 1992; Daly et al., 1993). Homozygous deletions in human small cell lung cancer (SCLC) cell lines were also found at 3p21 (Daly et al., 1993; Yamakawa et al., 1993; Kok et al., 1994) and 3p12 (Latif et al., 1992).

In human uterine cervical cancer, a common region of LOH was identified at 3p13-p21.1 (Kohno et al., 1993; Jones et al., 1994) and in 75\% of the cases allelic loss was detected at 3p13-p14.3 (Jones et al., 1992).

These findings can be taken to indicate that $3 p$ contains several suppressor genes, with $V H L$ as the most distal one and the cervical carcinoma deletion as the most proximal. The other solid tumors need more precise mapping in order to decide whether the same or closely adjacent regions are affected by deletions in $3 p$. As a first step toward a comparative study, we wished to map the $3 p$ losses in NPC in more detail, using CA repeat polymorphic markers.

\section{MATERIALS AND METHODS}

\section{Biopsies}

NPC biopsies were obtained from untreated patients collected at the Ear-Nose-Throat Hospital, Guangzhou Provincial Hospital, and Shanghai

\footnotetext{
Received December 22, 1995; accepted June 5, 1996.

Address reprint requests to Dr, Li-Fu Hu, MTC, Karolinska Institute, 17177 Stockholm, Sweden.
} 
Cancer Hospital, China. A portion of the tissue was subjected to histopathological examination, whereas the remainder was snap-frozen and kept at $-70^{\circ} \mathrm{C}$ for subsequent DNA analysis. All tumors were undifferentiated NPC according to the World Health Organization (WHO) classification.

Clinical staging of the tumors was performed according to the tumor-nodes-metastasis (TNM) classification. The extension of the primary tumor was indicated as tumor stage $T$. For $T 0$, the primary tumor was invisible, but histological examination showed a precancerous state. T1 indicated that the tumor was confined to one wall of the nasopharynx. In T2, the tumor had extended beyond two walls, but remained confined to the nasopharynx. In T3, the tumor had extended beyond the nasopharynx or involved the base of the skull. The T4 designation was used when the two alternatives of $\mathrm{T} 3$ occurred together. The $\mathrm{N}$ series of designations indicates the involvement of the regional lymph nodes. N0 indicates cases without palpable lymph nodes. N1 designates the involvement of a single, homolateral lymph node that remains smaller than $2 \times 2 \mathrm{~cm}$. N2 indicates contralateral, homolateral, or bilateral lymph nodes larger than $2 \times 2 \mathrm{~cm}$, but smaller than $8 \times 8 \mathrm{~cm}$, while N3 indicates lymph nodes larger than $8 \times 8$ $\mathrm{cm}$ or extending into the supraclavicular area $(\mathrm{Hu}$ et al., 1995).

Seventeen tumor samples from 17 patients were examined in parallel with normal lymphocyte DNA from the same donor. Twenty NPC biopsies from an equal number of patients where normal lymphocyte samples were not available were tested as well.

\section{DNA Extraction}

High molecular weight DNA was isolated from tumor tissue and blood lymphocytes from the same NPC patients by phenol extraction (Sambrook et al., 1989). To ascertain that the material contained a high proportion of tumor cells, we exploited the fact that low differentiated and anaplastic NPC carry 14-41 copies of EBV DNA per cell (Klein et al., 1974). All tumor samples were tested for presence of viral DNA by Southern blot hybridization using the $1.9 \mathrm{~kb}$ Xho1 fragment of BNLF1 (Hu et al., 1991). Raji DNA (50 copies per cell) was used as positive control. Only NPC tumor samples that contained more than 10 EBV DNA copies were included.

\section{Microsatellite Analysis}

Eighteen markers located on chromosome arm $3 p$ were used (Table 1). Fourteen of them were polymorphic microsatellite CA repeat markers. Polymerase chain reaction (PCR) primers were obtained from Scandinavian Gene Synthesis AB, ISOGEN Bioscience, and the Nordic Primer Resource (Department of Clinical Genetics, University Hospital) in Uppsala, Sweden.

PCR was carried out in a volume of $25 \mu \mathrm{l}$ containing 2.5-5.0 pmol of each primer, $0.2 \mathrm{mM}$ of each dNTP, 50-200 ng template DNA, and 1 unit of ampli Taq DNA polymerase from Perkin Elmer (Norwalk, CT) or DynaZyme from Finnzymes Oy. One of the paired primers $(0.25 \mathrm{pmol})$ in the reaction mixture was end-labeled with $\left[\gamma_{-}{ }^{32} \mathrm{P}\right]$ ATP using T4 polynucleotide kinase (Amersham, Buckinghamshire HP7 9NA, UK). Samples were processed through 35 cycles comprising $30 \mathrm{sec}$ at $94^{\circ} \mathrm{C}, 1 \mathrm{~min}$ at the appropriate annealing temperature, and $2 \mathrm{~min}$ at $72^{\circ} \mathrm{C}$ in a Techne PHC-3 and Perkin Elmer thermal cycler.

Aliquots of the amplified DNA were electrophoresed on denaturing $6 \%$ polyacrylamide DNA sequencing gels that were left to expose $\mathrm{X}$-ray films.

\section{RESULTS}

\section{Sensitivity of Marker}

Most markers in Table 1 are included in the consensus order established at the second-generation yeast artificial chromosome (YAC)-contig map of human chromosome 3 which integrates both physical and genetic data including somatic-cellhybrid analysis, YAC clones-end probes, ALUPCR and fingerprint data, and the current genetic map (Gemmill et al., 1995; Naylor et al., 1996a,b). In view of the fact that each tumor sample contains an unknown quantity of normal host cells, potentially capable of giving false positive signals, the percentage LOH figures must be considered conservative, minimum estimates. In order to assess the sensitivity of our conditions for microsatellite analysis, we performed titration experiments with artificial mixtures of signal positive and negative cells. Human and mouse DNAs were mixed in different proportions and microsatellite analysis was performed at standard conditions for several of our primers. Three different primers were tested, corresponding to high, low, and intermediate frequencies of LOH in the NPC samples, as detailed below. All three primers showed approximately the same sensitivity. We found a linear relation to signal intensity up to $30 \%$ of human DNA (Fig. 1). About $5 \%$ of human DNA could be detected against a background of $95 \%$ of mouse DNA. This 
TABLE I. CA Markers in the p26-3p/4 Region Used for the Allelic Loss Study

\begin{tabular}{|c|c|c|c|}
\hline Locus & $\begin{array}{l}\text { Marker } \\
\text { used for }\end{array}$ & Location & References $^{b}$ \\
\hline D3S। 307 & A & p26.3 & GI, G2, NI \\
\hline D3S 1297 & A & p26.3-p26.2 & $\mathrm{GI}, \mathrm{G} 2, \mathrm{NI}$ \\
\hline D3SI539 & B & p26 & GI, N2, Smith and Glover (1995) \\
\hline D3S1620 & B & p26.1-25.3 & $\mathrm{GI}, \mathrm{G} 2, \mathrm{NI}$ \\
\hline D3S 1560 & B & p26.1-25.3 & GI, G2, NI \\
\hline D3SI 304 & A & P25.3 & GI, G2, NI \\
\hline D3S1597 & B & P25.3 & GI, G2, NI \\
\hline VHL & B & p25.2 & $\mathrm{G} 2, \mathrm{NI}$ \\
\hline NLIZIO6R & B & p25.2-25.1 & Allikmets et al. (1994), NIc \\
\hline D3SI298 & A & p22.1 & $\mathrm{GI}, \mathrm{G} 2, \mathrm{NI}$ \\
\hline D3S 966 & A & p21.3 & A, NI, Jones et al. (1992) \\
\hline D3S 1029 & A & p21.31 & $A, G 2, N 1$ \\
\hline D3FI5S2 & $\mathbf{B}$ & p21.31 & $\mathrm{G} 2, \mathrm{NI}$ \\
\hline GNAI2 & $\mathbf{B}$ & p21.31 & $\mathrm{G} 2, \mathrm{NI}$ \\
\hline D3S1067 & A & p21.1-14.3 & N2, jones et al. (1992) \\
\hline D 351228 & A & p|4.3-14.1 & NI, N2, Jones et al. (1992) \\
\hline $\mathrm{D} 3 \mathrm{~S} 1217$ & A & p $\mid 4.2-14.1$ & N1, N2, Smith and Glover (1995) \\
\hline D3S 1210 & A & pl3 & G2, N1, N2 \\
\hline
\end{tabular}

${ }^{\mathrm{a}} \mathrm{A}=$ markers used in LOH study for all samples; $\mathrm{B}=$ markers used only for checking the deletion region or estimating the size of deletion.

'The localization of markers has been placed by these authors: A: Ariyama et al. (1995); GI: according to Genethon genetic map (Gyapay et al., I994); G2: Gemmill et al. (1995); NI: Naylor et al. (1996a); N2: Naylor et al. (1996b).

The marker (also called D3SI652) is not ordered at the second-generation YAC-contig map, but mapped by hybridization using a reference panel of somatic cell hybrids containing fragments of chromosome 3 and by FISH.

means that allelic imbalance can be detected even in the presence of $30 \%$ normal DNA contamination.

\section{Frequency of LOH in Chromosome 3}

The 10 microsatellite markers used in this study are listed in Table 1 . A total of 17 primary undifferentiated NPC were examined for LOH (Fig. 2). LOH was detected in 12 of the 17 tumors $(70 \%)$. The remaining cases retained both alleles at all informative sites between D3S1307 and D3S1210.

LOH was particularly frequent at the D3S1067 ( $9 / 15$ cases, $60 \%)$ and D3S1217 (7/12 cases, 58\%) loci.

Extensive $\mathrm{LOH}$ was detected in four samples: $\mathrm{T} 7, \mathrm{~T} 24, \mathrm{~T} 4$, and $\mathrm{T} 35$. The $\mathrm{T} 7$ tumor showed $\mathrm{LOH}$ for all informative markers, indicating that the entire short arm of chromosome 3 was lost. In one sample (T24), all markers distal to D3S1217 displayed $\mathrm{LOH}$, indicating the presence of a terminal deletion of $3 \mathrm{p}$. T3, T8, T10, T26, and T36 showed LOH of internal markers but maintained heterozygosity for more terminal markers. This is consistent with the presence of interstitial deletions. Only 1 of 11 tested samples (9\%) showed allelic loss at locus D3S1304 (3p25.3). One of 7 (14\%) showed LOH for marker D3S1228 (3p14.3p14.1).

\section{Frequently Deleted Regions}

Twelve of the 17 cases contained deletions. The pattern of allelic loss is presented in Figure 3. With the exception of the single sample mentioned above (T7) that was monosomic for the entire $3 p$, 11 of 12 tumors showed partial deletions. Nine tumors (T7, T4, T24, T35, T14, T13, T10, T8, and T3) showed a deletion in the 3p14.3-p21.1 region, as indicated by D3S1067 (9/15, 60\%). This coincides with the results of an LOH study in RCC (Foster et al., 1994). Seven of 12 tumors (58\%) that showed LOH at D3S1217 (3p14.2p14.1) also displayed $\mathrm{LOH}$ at marker D3S1067 (3p21.1-p14.3).

Six tumors (T4, T35, T8, T10, T13, and T14) showed a "zebra-like" pattern of LOH in that some markers showed LOH, whereas others located between them were still heterozygous. For verification of this pattern, we performed further tests with T35. In this tumor, the markers D3S1297 (3p26.3-p26.2) and D3S1298 (3p22.1) showed $\mathrm{LOH}$, whereas both alleles of the marker D3S1304 (3p25.3), located between them, were maintained without any sign of allelic imbalance. We subsequently tested two additional markers, D3S1560 on the telomeric and D3S1597 on the centromeric side of D3S1304. D3S1560 showed allelic imbalance, whereas D3S1597 had a normal 


\section{mouse $100 \% 95 \% 85 \% 70 \% 50 \% 0 \%$}

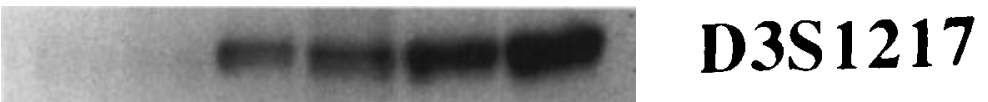

human $0 \% \quad 5 \% 15 \% 30 \% 50 \% 100 \%$

mouse $100 \% 95 \% 85 \% 70 \% 50 \% 0 \%$

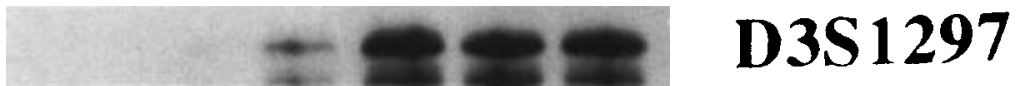

human $0 \% \quad 5 \% 15 \% 30 \% 50 \% 100 \%$

mouse $100 \% 95 \% 85 \% 70 \% 50 \% 0 \%$

D3S1304

\section{homan $0 \% 5 \% 15 \% 30 \% 50 \% 100 \%$}

Figure 1. Model experiment to test sensitivity of different microsatellite markers demonstrating minimal (D3S|304), intermediate (D3S1297), and maximal (D3S1217) allelic imbalance in NPC. Human and mouse DNAs were mixed in different proportions, and microsatel-

pattern. This result confirmed the existence of an allelic deletion at 3p26.1-25.3.

\section{Homozygous Deletion}

In addition to the samples reported above that were compared to matched lymphocytes from the same patient, we examined 26 additional NPC biopsies from patients whose lymphocyte samples were not available. In one of them, T62, the locus D3S1297, mapped at 3p26.2-p26.3, was not found (Fig. 3A). Ten other microsatellite markers were all maintained, including the marker D3S1307 that is adjacent to D3S1297. To confirm this result, the additional markers D3F15S2 (3p21.31), GNAI2 (3p21.31), and VHL (3p25.2) were tested as an internal control in duplex PCR, in parallel with D3S1297 and other markers already mentioned. lite analysis was performed under standard conditions. The results show linear dependence of signal intensity up to $30 \%$ of human DNA. All markers show comparable sensitivity.

The primers for D3S1297 gave no PCR products, in contrast to the other three primers that produced specific bands in the same reaction mixture. D3S1297 generated a weak, specific band with T62 DNA, however, if two subsequent PCR reactions were performed, each with 30 cycles. We suggest that this PCR product was generated by contaminating normal DNA in the tumor sample. If this interpretation is correct, it excludes the possibility that the deletion of the D2S1297 marker from the tumor tissue is spurious and due to polymorphism. In order to obtain some information on the size of the deletion, the two markers closest to the deletion were subsequently tested. One was a more distal marker (D3S1539) and one a more proximal marker (D3S1620). The primers for both markers generated two bands, without any allelic imbalance. This is additional proof of homozygous 
$\begin{array}{llllllllllllllllllll}\text { Marker } & \text { Locus } & \text { T7 } & \text { T24 } & \text { T4 } & \text { T35 } & \text { T3 } & \text { T8 } & \text { T10 } & \text { T13 } & \text { T14 } & \text { T26 } & \text { T36 } & \text { T41 } & \text { T5 } & \text { T6 } & \text { T16 } & \text { T25 } & \text { T37 } & \text { Allelic loss/ tested (\%) }\end{array}$

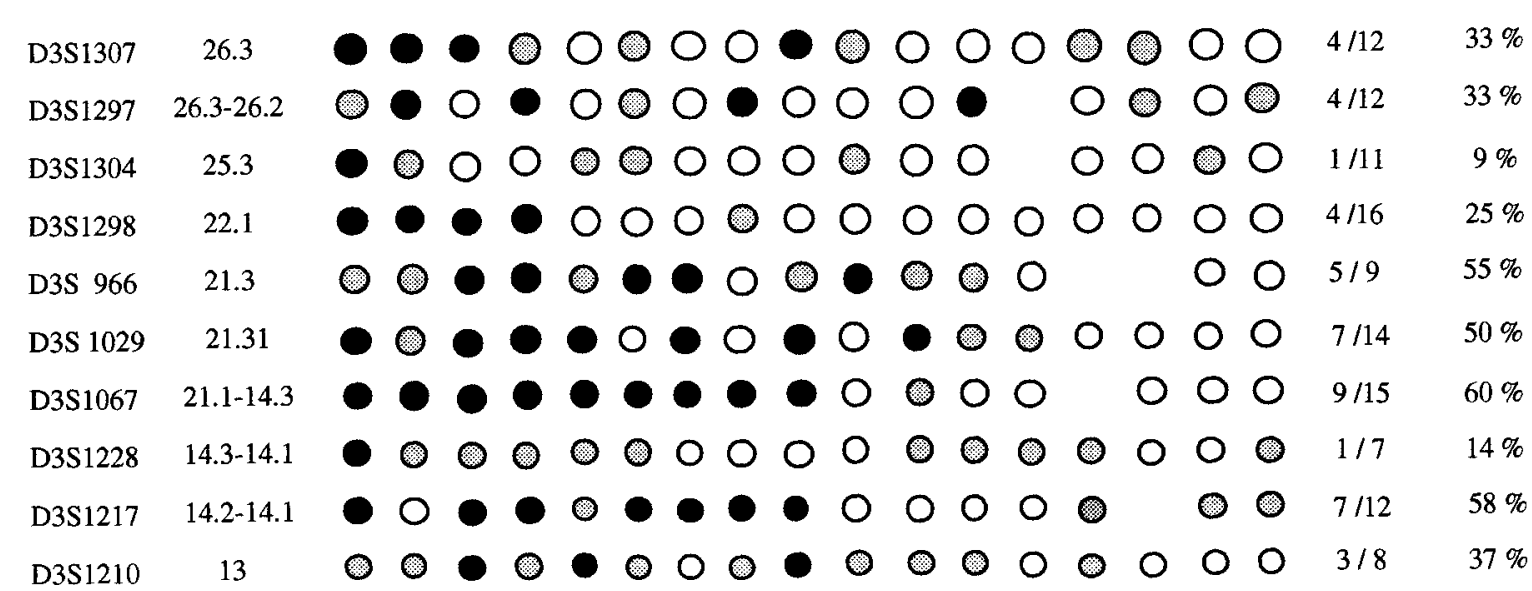

Figure 2. Schematic representation of LOH in 3p in 17 NPC. Each column corresponds to one NPC. Case numbers are shown at the top. The data were obtained by PCR over CA repeats with the markers in Table I. In each case, the tumor DNA was tested in parallel with lym-

deletion at this locus and indicates that the size of the deletion was less than $7 \mathrm{cM}$ (Fig. 3B).

\section{Comparison With Clinical Status}

Table 2 shows the extent of LOH in relation to clinical stage. Four tumors (T7, T24, T4, and T35) that showed extensive LOH (G4, see footnote to Table 2) were stage III-IV, and none of them was classified as stage II. Eight of the nine patients that showed LOH in the 3p21.1-p14.1 region were in stage III-IV. In contrast, 7 of $8 \mathrm{G1}$ patients who showed no LOH in this region were stage II.

Four of 9 tumors with LOH at 3p21.1-p14.3 had metastases, whereas only 1 of the 8 tumors without LOH had metastases.

\section{DISCUSSION}

It has been shown that multiple loci may be deleted or mutared within a single tumor type (Van der Hout et al., 1991). This can be exemplified by Wilms' tumor, where several loci on $11 \mathrm{p}$ may be lost or mutated (Jeanpierre et al., 1990). Also, the same locus may be lost in more than one tumor type (Brauch et al., 1990). Deletions of the short arm of chromosome 3 are found in many tumors, particularly in carcinomas. They may affect different $3 p$ regions in the same type of tumor. In human lung cancer, loci at 3p25,3p21-p22, and 3p13-p14 are most frequently deleted (Hibi et al., 1992; Yokoyama et al., 1992; Daly et al., 1993). Common regions of deletion have been identified at $3 \mathrm{p} 13$ p21.1 in endometrial cancer and at 3p13-p14.3 in phocyte DNA from the same patient. Some alleles in some cases were non-informative due to homozygosity. Empty space indicates that this sample was not tested due to shortage of materials. (O) Both alleles retained; $(\mathrm{O}) \mathrm{LOH}$; (O) non-informative.

cervical cancer (Jones et al., 1992). Two separate regions, 3p14-p13 and 3p26-p24, have been found to be independently deleted in some breast cancers (Chen et al., 1994).

LOH has been found in 3p22-p21, including D3S1298 and D3S1067 and proximal to D3S1235 and D3F15S2 in both lung cancer (Kok et al., 1987; Hibi et al., 1992) and other cancers such as RCC and gastric cancer (Yamakawa et al., 1993; Schneider et al., 1995; Van den Berg et al., 1995). A second region proximal to D3S1228 has shown frequent LOH in other cancers as well, such as cancer of the larynx and breast (Chen et al., 1994; Sun et al., 1995a). These data suggest that $3 p$ deletions may be different in different tumors.

As a step toward a comparative analysis, we attempted to map $3 p$ losses in NPC by examining 10 polymorphic microsatellite loci for allelic imbalance or deletion. The markers spanned the region 3 p13 to 3p25-26. Matched tumor-lymphocyte samples were examined from 17 patients. Twelve of the 17 analyzed samples (70\%) had LOH in 3p. The most frequently changed regions were $3 \mathrm{p} 21.1$ $14.3(60 \%)$ and $3 p 14.2-14.1$ (58\%).

Since we relied on only clear cases of $\mathrm{LOH}$, these figures may be considered minimal estimates. Admixture of normal tissue may obscure marker losses.

$\mathrm{LOH}$ at both the proximal and distal parts of $3 \mathrm{p}$, with markers retained between them, was observed in tumors $\mathrm{T} 4, \mathrm{~T} 35, \mathrm{~T} 8, \mathrm{~T} 10, \mathrm{~T} 13$, and $\mathrm{T} 14$ and suggests the occurrence of partial deletion and sometimes multiple deletions. A similar "zebra 
a.

$\begin{array}{llll}\text { GNA12 } & \text { GNA } & \text { 12+D3S1297 } & \text { D3S1297 } \\ \text { H } & \text { M } & \text { H } & \text { T61T62 M }\end{array}$

A

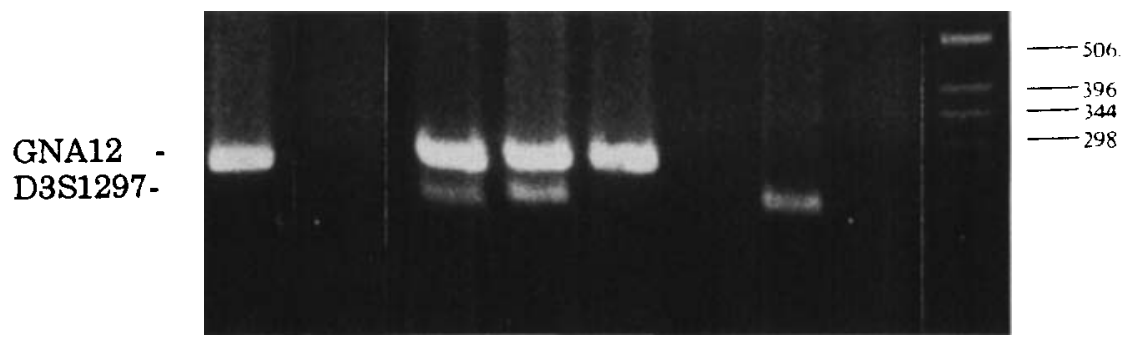
VHL VHL + D3F15S2
D3F15S2
H M T61T62 H M H M

D3F15S2 -

VHL

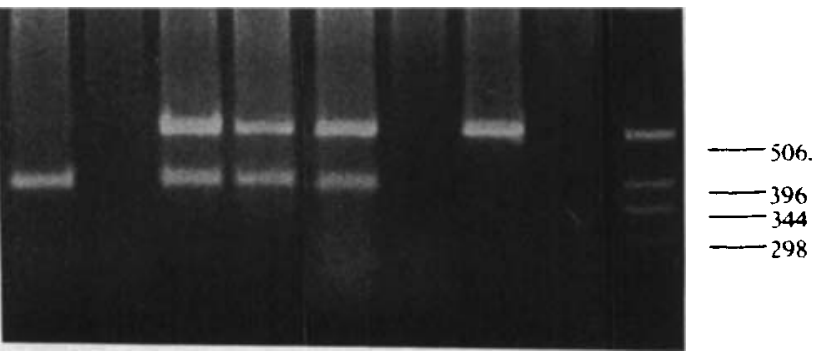

c.

NL1Z106 NL1Z106+GNA12 GNA12

H M T61T62 H M H M

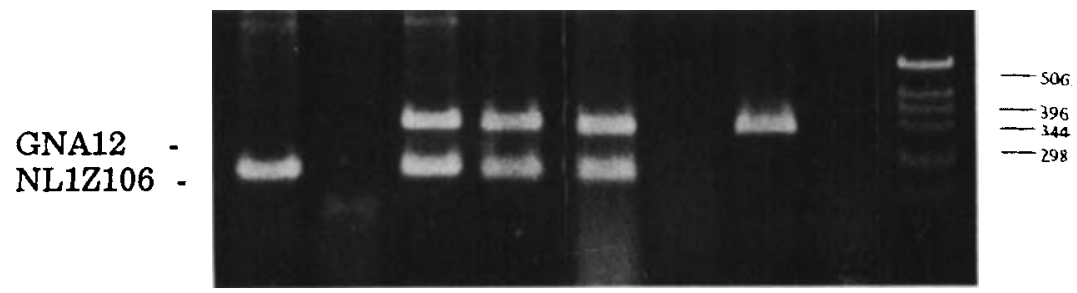

a.
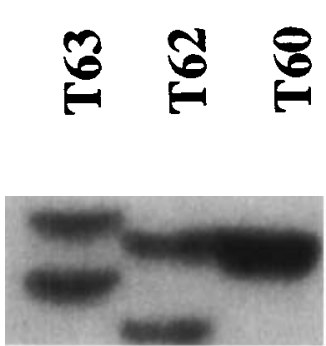

D3S1620 b.

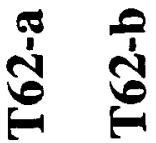

c.

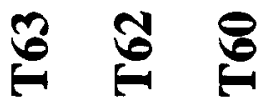

Figure 3. A: Detection of a homozygous deletion in tumor T62 Tumor DNA from another sample (T61), normal human lymphocyte DNA $(H)$, and mouse DNA $(M)$ were used as controls. Five additional markers surrounding D3SI 297 were analyzed: (a) simultaneous test of GNA/2 and D3SI297; (b) simultaneous test of VHL and D3FI5S2; (c) simultaneous test of NLIZ106R and GNAI2. B: Homozygous deletion in

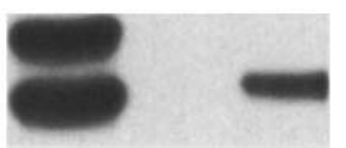

D3S1297

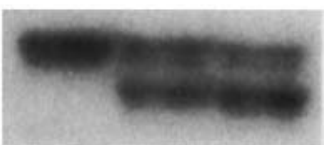

D3S1539

tumor T62. Two markers, D3SI539 (telomeric) and D3S1620 (centromeric) adjacent to the deleted D3SI 297 were used to check the deletion in three NPC samples. The D3S1297 marker was lost in the T62 tumor, whereas all markers were retained in three samples. T62-a and T62-b in the middle panel represent a single round and three rounds of 30 cycles PCR with marker D3S1297, respectively. 
TABLE 2. Relationship Between Clinical Stage and Allelic Loss on 3p

\begin{tabular}{|c|c|c|c|c|c|c|c|c|c|c|c|}
\hline \multirow[b]{2}{*}{ Name } & \multirow[b]{2}{*}{ Gender } & \multirow[b]{2}{*}{ Age (years) } & \multicolumn{3}{|c|}{ Tumor type } & \multirow{2}{*}{$\begin{array}{c}\text { Tumor } \\
\text { size } \\
\text { (T0-4) }\end{array}$} & \multirow{2}{*}{$\begin{array}{l}\text { Cervical } \\
\text { lymph } \\
\text { nodes }\end{array}$} & \multicolumn{2}{|c|}{ Hematogenous metastasis ${ }^{b}$} & \multirow{2}{*}{$\begin{array}{l}\text { Clinical } \\
\text { stages I-IV }\end{array}$} & \multirow{2}{*}{$\begin{array}{c}\text { Grade o } \\
\text { allelic } \\
\text { loss }^{c}\end{array}$} \\
\hline & & & C & G & M & & & Bone & Nerve & & \\
\hline T7 & $M$ & 65 & & & + & T3 & No & + & - & III & G4 \\
\hline T24 & $M$ & 55 & + & & & T3 & No & - & - & III & G4 \\
\hline T4 & $M$ & 50 & & & + & T4 & NO & + & + & IV & G4 \\
\hline T35 & $M$ & 45 & & & + & T4 & NO & + & + & IV & G4 \\
\hline T3 & $M$ & 65 & & & + & T3 & No & - & - & III & $\mathrm{G} 2$ \\
\hline T8 & $M$ & 47 & + & & & $\mathrm{T} 2$ & N3 & - & - & III & $\mathrm{G} 2$ \\
\hline T10 & $M$ & 64 & & & + & $\mathrm{T} 2$ & No & - & - & $\|$ & $\mathrm{G} 3$ \\
\hline TI3 & $M$ & 62 & + & & & T3 & No & - & - & III & G3 \\
\hline TI4 & $M$ & 61 & & & + & T4 & NI & + & + & IV & G3 \\
\hline T26 & $M$ & 56 & + & & & $\mathrm{T} 2$ & N2 & - & - & ॥ & GI \\
\hline T36 & $M$ & 58 & & & + & $\mathrm{T} 2$ & No & - & - & II & GI \\
\hline T4I & $M$ & 52 & + & & & $\mathrm{T} 2$ & No & - & - & II & GI \\
\hline T5 & $M$ & 65 & & & + & $\mathrm{T} 2$ & NO & - & - & II & GI \\
\hline T6 & $M$ & 19 & & + & & $\mathrm{T} 2$ & No & - & - & II & GI \\
\hline T16 & $F$ & 46 & & & + & $\mathrm{T} 2$ & No & - & + & III & GI \\
\hline $\mathrm{T} 25$ & $M$ & 53 & & & + & $\mathrm{T} 2$ & No & - & - & II & GI \\
\hline T37 & $F$ & 39 & + & & & $\mathrm{T} 3$ & No & - & - & II & GI \\
\hline
\end{tabular}

${ }^{\mathrm{a}} \mathrm{C}=$ cauliflower tumor; $\mathrm{M}=$ massive tumor; $\mathrm{G}=$ granular tumor.

'Bone $=$ local bone infiltration; nerves = local nerve infiltration.

'G4: extensive loss including marker D3S1067 and marker D3S1217; G3: loss of both markers D3S1067 and D3S1217; G2: loss of one marker, either D3SI067 or D3SI217; GI: no loss or loss of neither marker D3S1067 nor D3S1217.

pattern" has been reported in primary RCC (Lubinski et al., 1994; Van den Berg et al., 1995), lung carcinoma (Hibi et al., 1992; Yokoyama et al., 1992), and NPC (Lo et al., 1994). In one previous study on RCC (Kovacs et al., 1988), only terminal deletions were found in $3 \mathrm{p}$, with or without an associated non-reciprocal translocation.

That marker D3S1304 in 3p25.3 was retained in T35 was confirmed by the use of markers on both sides of the region. The more telomeric marker (D3S1560) was deleted, whereas the more centromeric marker (D3S1597) was retained.

One possible source of error might stem from a difference in the sensitivity of the different markers to normal tissue contamination. Would a marker signaling $\mathrm{LOH}$ in $58-60 \%$ of the tumors be less sensitive to normal tissue contamination than a marker that was lost in only $9 \%$ of the tumors? This was approached by model experiments with artificial mixtures of human and mouse DNA. These experiments indicate that $\mathrm{LOH}$ from tumors could be detected in the presence of $30 \%$ normal tissue contamination, with markers showing high, low, and intermediate loss frequencies from the tumor material (Fig. 1).

The homozygous deletion found in the T62 tumor is of particular interest. Genetic polymorphism is unlikely since a weak signal was detected when the number of cycles was increased, probably derived from contaminating normal tissue. In this region, allelic loss was localized between the VHL locus and the more distal D3S1304 marker in the $\mathrm{T} 13$, T14, and T41 tumors; the same region was involved in homozygous deletion at D3S1297 in T62. Frequent losses have also been found in the same region in esophageal and oral cancer (Wu et al., 1994; Ogasawara et al., 1995).

LOH in $3 \mathrm{p}$ in NPC tumors has been studied previously. Huang et al. (1991) reported $100 \%$ LOH at two chromosomal loci: $R A F 1$ (10/10 cases at $3 \mathrm{p} 25)$ and D3S3 locus $(9 / 9$ cases at $3 \mathrm{p} 14)$ by Southern blot hybridization using chromosome 3 specific polymorphic probes. In another study, they showed that LOH was observed in 18 of $27 \mathrm{NPC}$ biopsies (67\%; Lo et al., 1994). A high frequency of LOH was found at several loci: D3S1038 (3p25) in 9/17 informative cases (53\%), D3S1228 (3p14.3p14.1) in $7 / 14$ cases (50\%), D3S659 (3p13) in 10/20 cases $(50 \%)$, and D3S1076 (3p21.1) in 9/19 cases (47.4\%) using CA marker analysis (Lo et al., 1994). We find the most frequent deletions at D3S1067 (3p21.1-p14.3; 60\%) and D3S1217 (3p14.2-p14.1; $58 \%$ ). Our results show LOH on $3 p$ in $70 \%$ of NPC, which is in line with previous findings of $67 \%$ using 
the same methodology (Lo et al., 1994). There is, however, a discordance regarding the precise localization of the most frequently deleted regions. In particular, Lo et al. (1994) found 53\% allelic deletion at $3 \mathrm{p} 25$.

The extent of LOH appeared to be correlated with tumor progression, as tumors in the more advanced stages III and IV showed a larger frequency of LOH than did tumors in stages I and II. The difference was significant $(P<0.005)$, judged by the Fisher exact, two-tailed method. This finding is consistent with the increase of $\mathrm{LOH}$ associated with progression in breast cancer and other tumors (Eiriksdottir et al., 1995). In the case of NPC, this point needs confirmation in larger material.

\section{ACKNOWLEDGMENTS}

We are grateful to Dr. Stefan Imreh for constructive discussion. This study was supported by the Swedish Cancer Society, Swedish Agency for Research Cooperation With Developing Countries (SAREC), Royal Swedish Academy of Sciences, King Gustaf V:S Jubilee fund, Cancer Foundation in Stockholm, Medical Research Council and Swedish Medical Association, Robert Lundbergs Minnesfound, and Karolinska Institute. L.-F.H. and F.C. were recipients of a fellowship from Karolinska Institute and CRI/Concern, the National Science Foundation.

\section{REFERENCES}

Allikmets R, Kashuba V, Pettersson B, Gizatulin R, Lebedeva T, Kholodnyuk I, Bannikov V, Petrov N, Zakharyev V, Winberg G, Modi W, Dean M, Uhlen M, Kisselev L, Klein G, Zabarovsky E (1994) Not 1 linking clones as a tool for joining physical and genetic maps of the human genome. Genomics 19:303-309.

Ariyama T, Kimura T, Yamakawa K, Nakamura Y, Abe T, Inazawa $\mathrm{J}$ (1995) Precise ordering of 26 cosmid markers on chromosome region $3 \mathrm{p} 23-\mathrm{p} 21.3$ by two-color FISH on human prophase chromosomes and stretched DNAs. Cytogenet Cell Genet 70:129133.

Brauch H, Tory K, Kotler F, Gasdar A, Pettingill OS, Johnson B, Grasiano S, Winton T, Buys C, Sorenson G, Poiesz B, Minna J, Zbar B (1990) Molecular mapping of deletion sites in the short arm of chromosome 3 in human lung cancer. Genes Chromosom Cancer 1:247-255.

Chen L-C, Matsumura K, Deng G, Kurisu W, Ljung B-M, Lerman MI, Waldman FM, Smith HS (1994) Deletion of two separate regions on chromosome $3 \mathrm{p}$ in breast cancers. Cancer Res 54: 3021-3024.

Daly MC, Xiang R-H, Buchhagen D, Hensel CH, Garcia DK, Killary AM, Minna JD, Naylor SL (1993) A homozygous deletion on chromosome 3 in a small cell lung cancer cell line correlates with a region of tumor suppressor activity. Oncogene 8:17211729.

Eiriksdottir G, Bergthorsson JT, Sigurdsson H, Gudmundsson J, Skirnisdottir S, Egilsson V, Barkardottir RB, Ingvarsson S (1995) Mapping of chromosome 3 alterations in human breast cancer using microsatellite PCR markers: Correlation with clinical variables. Int J Oncol 6:369-375.

Foster K, Crossey PA, Cairns P, et al. (1994) Molecular genetic investigation of sporadic renal cell carcinoma: Analysis of allele loss on chromosome 3p, 5q, 11p, 17 and 22. Br J Cancer 69:230234.

Gemmill RM, Chumakov I, Scott P, Waggoner B, Rigault P, Cypser
J, Chen Q, Welssenbach J, Gardiner K, Wang H, Pekarsky Y, Le Gall I, Le Paslier D, Guillou S, Li E, Robinson L, Hahner L, Todd S, Cohen D, Drabkin HA (1995) A second-generation YAC contig map of human chromosome 3. Nature 377:299-319.

Gnarra JR, Tory K, Weng Y, Schmidt L, Wei MH, Li H, Latif F, Lius S, Chen F, Duh FM, Lubensky I, Duan DR, Florence C. Pozzatti R, Walther MM, Bander MI, Grossman HB, Brauch H, Pomer S, Brooks JD, Isaacs WB, Lerman MI, Zbar B, Lineham WM (1994) Mutations of the VHL tumor suppressor gene in renal carcinoma. Nat Genet 7:85-89.

Gyapay G, Morissette J, Vignal A, Dib C, Fizames C, Philippe M, Marc S, Bernardi G, Lathrop M, Weissenbach J (1994) The 1993-94 Genethon human genetic linkage map. Nat Genet $7: 246$.

Hibi K, Takahashi T, Yamakawa K, Ueda R, Sekido Y, Ariyoshi Y, Suyama M, Takagi H, Nakamura Y, Takahashi T (1992) Three distinct regions involved in $3 p$ deletion in human lung cancer. Oncogene 7:445-449.

Hu L-F, Zabaruvsky ER, Chen F, Cao S-L, Ernberg I, Klein G, Winberg $G$ (1991) Isolation and sequencing of the EBV BNLF-1 gene (LMP) from a Chinese NPC. J Gen Virol 72:2399.

Hu L-F, Chen F, Zhen Q-F, Zhang Y-W, Luo Y, Zheng X, Winberg G, Ernberg I, Klein $G$ (1995) Differences in the growth pattern and clinical course of EBV-LMP1 expressing and nonexpressing nasopharyngeal carcinoma. Eur J Cancer 31A:658660 .

Huang DP, Ho JHC, Chan PHK, Lui M (1989) Cytogenetics of undifferentiated nasopharyngeal carcinoma xenografts from southern Chinese. Int J Cancer 43:936-939.

Huang DP, Lo KW, Choi PHK, Ng AYT, Tsao SY, Yin GKC, Lee JKC (1991) Loss of heterozygosity on the short arm of chromosome 3 in nasopharyngeal carcinoma. Cancer Genet Cytogenet 54:91-99.

Jeanpierre C, Antignac C, Beroud C, Lavedan C, Henry I, Saunders G, Williams B, Glaser T, Junien C (1990) Constitutional and somatic deletions of two different regions of maternal chromosome 11 in Wilms' tumor. Genomics 7:434.

Jones MH, Yamakawa K, Nakamura Y (1992) Isolation and characterization of 19 dinucleotide repeat polymorphisms on chromosome 3p. Hum Mol Genet 1:1631-1634.

Klein G, Giovanella BC, Lindahl T, Fialkow PJ, Singh S, Stehlin JS (1974) Direct evidence for the presence of Epstein-Barr virus DNA and nuclear antigen in malignant epithelial cells from patients with poorly differentiated carcinoma of the nasopharynx. Proc Natl Acad Sci USA 71:4737-4741.

Kohno T, Takayama $H$, Hamaguchi $M$, Takano $H$, Yamaguchi N, Tsuda $H$, Hirohashi S, Vissing $H$, Shimizu M, Oshimura M, Yokota J (1993) Deletion mapping of chromosome 3p in human uterine cervical cancer. Oncogene 8:1825-1832.

Kok K, Osinga J, Carritt B, Davis MB, van der Hout AH, van der Veen AY, Landsvater RM, de Leij LMFH, Berendsen HH, Postmus PE, Poppema S, Buys CHM (1987) Deletion of DNA sequence at region $3 \mathrm{p} 21$ in all major types of lung cancer. Nature 330:578-581.

Kok K, van den Berg A, Veldhuis PMJF, van der Veen AY, Franke M, Schoenmakers EFPM, Hulsbeek MMF, van der Hout AH, de Leij L, van de Ven W, Buys CHCM (1994) A homozygous deletion in a small cell lung cancer cell line involving a 3 p21 region with a marked instability in yeast artificial chromosome. Cancer Res 54:4183-4187.

Kovacs G, Eladsson R, Boldog F, Ingvarsson S, Muller-Brechlin R, Klein G, Sumegi J (1988) Consistent chromosome 3p deletion and loss of heterozygosity in renal cell carcinoma. Proc Natl Acad Sci USA $85: 1571-1575$.

Latif F, Tory K, Modi WS, Graziano SL, Gamble G, Douglas J, Heppell-parton AC, Rabbitts PH, Zbar B, Lerman MI (1992) Molecular characterization of a large homozygous deletion in the small cell lung cancer cell line U2020: A strategy for cloning the putative tumor suppressor gene. Genes Chromosom Cancer 5:119-127.

Lo KK, Tsao SW, Leung SF, Choi PHK, Lee JCK, Huang DP (1994) Detailed deletion mapping on the short chromosome 3 in nasopharyngeal carcinomas. Int J Oncol 4:1359-1364.

Lubinski J, Hadaczek P, Podolski J, et al. (1994) Common regions of deletion in chromosome regions $3 \mathrm{p} 12$ and $3 \mathrm{p} 14.2$ in primary clear cell renal carcinomas. Cancer Res 54:3710-3713.

Naylor SL, Carritt B, Boileau C, et al. (1996a) Report of the Sixth International Workshop on Human Chromosome 3. Cytogenet Cell Genet 72:255-270.

Naylor SL, Moore S, Garcia D, Xiang X, Xin X, Moherer M, Reus 
B, Linn R, Stanton V, O'Connell P, Leach RJ (1996b) Mapping 638 STSs to region of human chromosome 3 . Cytogenet Cell Genet 72:90-94.

Ogasawara S, Maesawa C, Tamura G, Satodate R (1995) Frequent microsatellite alterations on chromosome $3 p$ in eospharyngeal squamous cell carcinoma. Cancer Res 55:891-894.

Sambrook J, Fritsch EF, Maniatis T (1989) Molecular Cloning: A Laboratory Manual. 2nd Ed. Cold Spring Harbor, NY: Cold Spring Harbor Laboratory Press.

Schneider BG, Pulitzer DR, Brown RD, Prihoda TJ, Bostwick DG, Saldivar V, Rodriguez-Martinez HA, Gutierrez-Diaz CME, O'Connell P (1995) Allelic imbalance in gastric cancer: An affected site on chromosome arm 3p. Genes Chromosom Cancer $13: 263-271$.

Shuin T, Kondo K, Torigoe S, et al. (1994) Frequent somatic mutations and loss of heterozygosity of the von Hippel-Lindau tumor suppressor gene in primary human renal cell carcinoma. Cancer Res 54:2852-2855.

Smith DI, Glover TW (1995) Report of the Fifth International Workshop on Human Chromosome 3 Mapping. Cytogenet Cell Genet 68:125-146.

Sun PC, EI-Mofty SK, Haughey BH, Scholnic SB (1995a) Allelic loss in squamous cell carcinomas of the larynx: Discordance between primary and metastatic tumors. Genes Chromosom Cancer $14: 145-148$

Sun Y, Hildesheim A, Li H, Lanier AP, Cao Y, Yao K-T, Yang C-S, Colburn NH (1995b) The von Hippel-Lindau (VHL) disease tumor-suppressor gene is not mutated in nasopharyngeal carcinoma. Int J Cancer 60:437-438.

Takahashi E, Yamakawa K, Nakamura Y, Hori T (1992) A high resolution cytogenetic map of human chromosome 3: Localization of 291 new cosmid markers by direct R-banding fluorescence in situ hybridization. Genomics 13:1047-1055.
Van den Berg M, Hulsbeek MMF, de Jong D, Kok K, Veldhuis PMJF, Roche J, Buys CHCM (1995) A major role for a 3p21 region and lack of involvement of the $t(3 ; 8)$ breakpoint region in the development of renal cell carcinoma suggested by loss of heterozygosity analysis. Genes Chromosom Cancer 15:64-72.

van der Hout AH, van der Vlies P, Wijmenga C, Li FP, Oosterhuis JW, Buys CHC (1991) The region of common allelic losses in sporadic real cell carcinoma is bordered by the loci D3S2 and THRB. Genomics 11:537-542.

van der Hout $\mathrm{AH}$, van der Berg E, van der Vlies P, Dijkhuizen T, Störkel S, Oosterhuis JW, de Jong B, Buys CHCM (1993) Loss of heterozygosity at the short chromosome 3 in renal cell cancer correlates with the cytological tumor type. Int J Cancer 53:353357.

Wilbelm M, Bugert P, Kenck C, Staehier G, Kovacs G (1995) Terminal deletion of chromosome $3 p$ sequences in nonpapillary renal cell carcinomas: A breakpoint cluster between loci D3S1285 and D3S1603. Cancer Res 55.

Wu CL, Sloan P, Read AP, Harris R, Thakker N (1994) Deletion mapping on the short arm of chromosome 3 in squamous cell carcinoma of the oral cavity. Cancer Res 54:6484-6488.

Yamakawa K, Morita R, Takahashi E, Hori T, Ishikawa J, Nakamura $Y$ (1991) A detailed deletion mapping of the short arm of chromosome 3 in sporadic renal cell carcinoma. Cancer Res 51: 4707-4711.

Yamakawa K, Takahachi T, Horio Y, Murata Y, Tahakachi E, Hibi K, Yokayama S, Ueda R, Takahashi T, Nakamura Y (1993) Frequent homozygous deletion in lung cancer cell lines detected by a DNA marker located at 3p21.3-p22. Oncogene 8:327-330.

Yokoyama S, Yamakawa K, Tsuchiya E, Murata M, Sekiyama S, Nakamura Y (1992) Deletion mapping on the short arm of chromosome 3 in squamous cell carcinoma and adenocarcinoma of the lung. Cancer Res 52:873-877. 